\title{
The expressiveness of a university professor in his classroom performance: analysis of verbal resources and implications for nursing ${ }^{1}$
}

\author{
Cristiane Conceição Romano² \\ Liliana Amorim Alves ${ }^{2}$ \\ lara Aparecida de Oliveira Secco ${ }^{3}$ \\ Lilian Neto Aguiar Ricz ${ }^{4}$ \\ Maria Lúcia do Carmo Cruz Robazzi ${ }^{5}$
}

\begin{abstract}
Expressiveness is the ability of individuals to make their thoughts alive through language and body, effectively transmitting information. This study investigated the expressiveness of a university professor during nursing classes in relation to verbal resources from the perspective of students. This descriptive and quantitative study was carried out in a Higher Education Institution using specific instruments to assess expressiveness. The professor's class was video recorded and the video was first assessed by three speech and language experts and later assessed by 141 students with whom he had no previous contact. The results reveal that students and experts agreed in relation to the professors' expressive skills, which proved the ability of students to evaluate this communication skill.
\end{abstract}

Descriptors: Communication; Teacher of Nursing; Speech; Language and Hearing Sciences.

\footnotetext{
${ }^{1}$ Paper extracted from Master's Thesis "O julgamento da expressividade do professor universitário de enfermagem ministrando aula" presented to Escola de Enfermagem de Ribeirão Preto, Universidade de São Paulo, WHO Collaborating Centre for Nursing Research Development, SP, Brazil.

2 Audiologist, Doctoral Student in Nursing, Escola de Enfermagem de Ribeirão Preto, Universidade de São Paulo, WHO Collaborating Centre for Nursing Research Development, SP, Brazil. E-mail: Cristiane - cristianeromano@yahoo.com.br, Liliana - liliana@eerp.usp.br.

${ }^{3}$ RN, Ph.D. in Nursing, Professor, Universidade Norte do Paraná, PR, Brazil. Hospital Universitário, Universidade Estadual de Londrina, Paraná, PR, Brazil. E-mail: iarasecco@sercomtel.com.br.

${ }^{4}$ Audiologist, Ph.D. in Medicine, Profesor, Faculdade de Medicina de Ribeirão Preto, Universidade de São Paulo, SP, Brazil. E-mail: liricz@fmrp.usp.br.

${ }^{5}$ RN, Ph.D. in Nursing, Full Professor, Escola de Enfermagem de Ribeirão Preto, Universidade de São Paulo, WHO Collaborating Centre for Nursing Research Development, SP, Brazil. E-mail: avrmlccr@eerp.usp.br.
}

Corresponding Author:

Maria Lúcia do Carmo Cruz Robazzi

Universidade de São Paulo. Escola de Enfermagem de Ribeirão Preto

Departamento de Enfermagem Geral e Especializada

Av. dos Bandeirantes, 3900

Bairro: Monte Alegre

CEP 14040-902, Ribeirão Preto, SP, Brasil

E-mail: avrmlccr@eerp.usp.br 


\title{
A expressividade do docente universitário durante sua atuação na sala de aula: análise dos recursos verbais utilizados e suas implicações para a enfermagem
}

A expressividade é a capacidade de o indivíduo tornar vivo seu pensamento pela linguagem e pela expressão corporal, permitindo a transmissão de informações de modo efetivo. O presente estudo objetivou investigar a expressividade do docente universitário de enfermagem ministrando aula, em relação aos seus recursos verbais, a partir do julgamento dos alunos. Trata-se de investigação descritiva, quantitativa, desenvolvida em uma instituição de ensino superior, para a qual foram utilizados instrumentos específicos de avaliação da expressividade. Realizou-se a filmagem de uma aula do referido docente, que foi primeiramente avaliado por três experts fonoaudiólogos e, depois, submetido ao julgamento por parte de 141 alunos que não haviam tido contato prévio com o mesmo. Os resultados mostraram que alunos e experts foram concordantes em seu julgamento sobre as habilidades expressivas do professor universitário de enfermagem, o que comprovou a capacidade e a propriedade dos discentes na avaliação dessa habilidade de comunicação.

Descritores: Comunicação; Docentes de Enfermagem; Fonoaudiologia.

\section{La expresividad del profesor universitario durante su actuación en la sala de clases: análisis de los recursos verbales utilizados y sus implicaciones para la enfermeira}

\begin{abstract}
La expresividad es la capacidad del individuo de tornar vivo su pensamiento por medio del lenguaje y por la expresión corporal, permitiendo la transmisión de informaciones de modo efectivo. El presente estudio objetivó investigar la expresividad del profesor universitario de enfermería dando clases en relación a sus recursos verbales, a partir de la evaluación de los alumnos. Se trata de investigación descriptiva, cuantitativa, desarrollada en una Institución de Enseñanza Superior, para lo cual fueron utilizados instrumentos específicos de evaluación de la expresividad. Se realizó una película de una clase del referido profesor, que fue primeramente evaluada por tres expertos fonoaudiólogos y después sometida a evaluación por parte de 141 alumnos que no habían tenido contacto previo con el mismo. Los resultados mostraron que alumnos y expertos coincidieron en su evaluación sobre las habilidades expresivas del profesor universitario de enfermería, lo que comprobó la capacidad y la propiedad de los estudiantes en la evaluación de esa habilidad de comunicación.
\end{abstract}

Descriptores: Comunicación; Docentes de Enfermería; Fonoaudiología.

\section{Introduction}

The word 'communication' originates from the Latin word communicatione (common), which means to participate, take common action, to relate with live and conscious beings, to make something common among beings, be it information, sensation or emotions, among other objects ${ }^{(1)}$. Through various connections and the exchange of information, a message is transmitted and understood through the communication process and enables learning, resolution of activities, motivation, and cooperation, in order to obtain the best results in workplaces(2). Individuals with communication skills present the interaction of various segmental elements (vowels and consonants) and prosodic characteristics (rhythm, intonation, quality of voice, speech rate, pauses 
and patterns of accents) and relationships established between sound and meaning(3). Through this interaction, individuals transmit a message with quality, creating an inter-relationship between transmitter and receptor.

Communication is a process related to expressiveness. An expressive person is communicative, has the ability to exchange ideas, talk, dialog and properly communicate information. Expressiveness is considered the quality of what is expressive, belongs to the communication process and is inseparable from it ${ }^{(3)}$. It is the ability of an individual to make his/her thought alive through language and body expression and then seek arguments to incite in another the wish to think together and construct an idea(4); it is a way to use communicative resources, generating either negative or positive impressions, pleasant or not, in the listener(5). It is related to the speaker's emotions and attitudes; the way a person talks and gesticulates (the expression a person transfers to what is meant) will reflect on one's attitude in the face of the explained subject, and will undoubtedly express one's emotions ${ }^{(6)}$.

There are professions that require a greater use of communication and expressiveness, and professors are included among them; these must effectively transmit didactic content to students.

In college teaching, professors face the challenge of preparing professionals to be qualified citizens, able to think, reflect and perform critical analyses. For that, a relationship with students is required. Among other means, such a relationship can be achieved through a quality communication process, that is, with expressiveness, since it is also responsible for facilitating the learning process on the part of students. Students are likely to pay attention and assimilate content better if the professor has good expressiveness. However, little attention has been paid to specifically preparing professors to act within a classroom. A lack of concern with the didactics of this professional is related to one of the gaps found in their education, that is, lack of knowledge concerning the importance of professor performance in teaching(6). Improving such skills is indicated as one of the main factors that can improve quality of education.

In nursing, such education should be strongly based on mastering scientific knowledge and investigative work in the teaching-learning process; the task of professors is to appropriate scientific, technical and technological tools regarding political, social, economic and cultural development thought so as to be able to think and generate solutions. Their practice should go beyond the mere transmission of information; in addition to technical and scientific competence, being politically committed is essential(7).

However, even if professors competently master knowledge, they will not be able to effectively transmit knowledge if they are not communicative and lack expressiveness. Expressiveness leads the interaction between the master and his/her disciples, facilitating the transmission of knowledge ${ }^{(6)}$.

We add that in a profession such as nursing, in which we deal with individuals who often depend on complex care, the education of nurses should not be compromised if one wishes to avoid harm to those patients who will be under the care of these professionals.

Hence, expressiveness can be assessed and serve as a "thermometer" for professors, since an inexpressive educator may harm the teaching-learning process. Considering that undergraduate students should not be mere spectators but active participants in their own educational process, their assessment concerning teaching and the professor can provide knowledge concerning the elements required by professors to redirect their expressiveness, finding ways to make it more appropriate.

The relevance of this study lies on the fact this is a topic seldom addressed; there is a small number of studies addressing the expressiveness of higher education professors, both in the nursing field and in other health fields. Therefore, the following guiding question was used: "Do higher nursing education professors, through the use of their verbal resources, expressively transmit content to their students?"

We believe that undergraduate nursing students are able to properly evaluate professors during contact in the classroom. Hence, the assessment of these students concerning the expressive skills of professors can be consistent with the assessment of speech language experts. Given the preceding discussion, this study presents an assessment of nursing professors' expressiveness during classes in relation to their verbal resources and expressive skills from the perspective of both experts and undergraduate students.

\section{Method}

This descriptive study with a quantitative approach was carried out in Ribeirão Preto, SP, Brazil in a Higher Education Institution (HEI) in nursing, mostly composed 
of health professionals, mainly nurses. There were 96 professors active in this institution in 2010, all of whom were responsible for undergraduate courses and 567 undergraduate students at the time of data collection, distributed over eight semesters of the bachelor's program and ten semesters of the nursing diploma program (325 from the bachelor's and 242 from the diploma's program).

The study's participants included professors and nursing undergraduates attending the HEI. The inclusion criteria used for the professors were: being a faculty member at the studied HEI, working in regular academic activity, for more than one year at the studied institution, being unfamiliar with students for teaching theoretical-practical content in semesters after those attended by the students participating in the study, consenting to participate in the study. Three professors at HEI, all nurses, were contacted. These would have their expressiveness assessed during classes. One refused and one agreed to participate in the study and is called Participant Professor (PP). The third agreed to be the Test-Professor (TP) provided only that the reliability of the questionnaire was performed by speech language experts.

The inclusion criteria used for selecting the students were: being a regular student at the HEI, being enrolled in courses from the first four semesters of the bachelor's and diploma's programs, not being familiar with the professors being assessed in relation to their expressiveness, and agreeing to participate in the study. A total of 167 students were initially included in the study, all were enrolled in the first and second years of the two programs available at the HEI, totaling four classes. Classes 1 and 2 were composed of first-year students from the bachelor's and the diploma's programs, and classes 3 and 4 were composed of second-year students from both programs. These students represented $29.4 \%$ of the total undergraduate students at HEI and $64.23 \%$ of the total first and second-year students.

One class composed of 26 students was excluded from the study because bias was observed during the data collection process. (The students were eager to return the questionnaires and leave the classroom, not paying attention to the questionnaire intended to assess the professor's expressiveness.) Given this fact, the sample was then composed of 141 students, $24.8 \%$ of the 567 students attending the HEI and $54.23 \%$ in relation to the total of the 260 first and second-year students.
The following stages were established to put this study into operation: Stage 1 - Preparation of instruments: the Speech Assessment Protocol (SAP) was used as the basic instrument to evaluate the professors' expressiveness ${ }^{(8)}$. This protocol is divided into three items: verbal resources, vocal resources and non-verbal resources. Only the item 'verbal resources' (type of voice, vocal style, loudness, pitch, articulation, speech rate, coordination of breathing, pronunciation and articulation was evaluated in this study.

An instrument called Students' Assessment Questionnaire (SAQ1), properly adapted to $\mathrm{SAP}^{(8)}$, was developed to avoid potential difficulties in students understanding specific terms used in the speech, language and hearing field. This questionnaire contained multiple choice, closed questions, addressing questions from $\mathrm{SAP}^{(8)}$, to identify the assessment of students in relation to professors' verbal resources. Students should check the answer they deemed to be the most appropriate.

Stage 2 - The reliability of the Students' Assessment Questionnaire was verified assessing a video of the Test Professor (TP). Three speech language experts were invited to judge the students' questionnaire. A technician from the studied institution filmed the TP for one hour while giving a lecture to a group of 80 students-who previously consented to the filming and were not otherwise participating in the study. The film was then edited according to the following criteria: two minutes from the beginning of the lecture, two minutes from the middle of the lecture and another two minutes from the end were selected and converted into a DVD, totaling six minutes of recording.

This DVD was sent to the previously contacted experts jointly with the students' questionnaire for evaluation. The process of sending the material and having it returned took one month. All the experts observations were implemented, resulting in a modified questionnaire (SAQ2).

Stage 3 - Participant Professor (PP) was assessed by the experts according to the SAP: the PP professor was filmed by a technician from the studied institution during a lecture presented to a class of senior students from the bachelor's program at the HEI. The movie was edited according to the same criteria used to edit the TP's movie and a total of six minutes were converted into a DVD. The experts assessed the professor's verbal resources according to $\mathrm{SAP}^{(8)}$. The evaluation material was returned after one month. 
Stage 4 - The students assessed PP according to questionnaire SAQ2: the questionnaire was applied to four classes of students enrolled at the HEI (first and second years of the Bachelor's program and the first and second years of the Diploma program). These students were chosen according to previously mentioned criteria; this professor had not previously lectured to these students. Data collection took 30 minutes and was held in the classrooms after authorization from the professors giving the classes was obtained. In most classes, the professors gave 30 minutes for responding to the questionnaire after the first period of 1 hour and 30 minutes to 2 hours of class. The professor responsible for class 4, however, allowed students to answer the questionnaire only at the end of the class. While the students from classes 1 to 3 took 25 to 30 minutes in average to fill in the instrument, the students from class 4 only took 10 minutes. In addition to the rapidity that the questionnaire was filled in, many answers were not provided.

This study's first author, a speech language hearing therapist, complied with the following sequence at the time of data collection: presented the study's objectives, distributed free and informed consent terms, collected the signed terms, distributed the SAQ2 questionnaires, explained how to fill them out; presented the PP'S DVD; presented the DVD a second time if required; requested that students answer the questionnaire by themselves; collected the questionnaires; and thanked students for their participation. Data collection was initiated after the study's project was submitted to and approved by the HEI Ethics Research Committee (No. 0517/2005). All the participants (students, PP and TP) received clarification concerning the study's objectives, to voluntarily participate in it, and signed free and informed consent terms according to the guidelines provided by Resolution 196/96, Ministry of Health(9).

\section{Results}

PT is a nurse more than 50 years old with experience in teaching, research and community/extension services; this professor taught for more than 30 years at the studied HEI. PP is also a nurse, between 40 and 50 years old, who has worked at the HEI for eight years and also has experience in teaching, research and community/ extension services. Students were mostly women (more than $90 \%$ ) and young (between 18 and 23 years of age) enrolled in the bachelor's and diploma programs.
According to the three speech and language experts who assessed the expressiveness of the nursing professor through the verbal resources of $\mathrm{SAP}^{(8)}$, based on a video of PP: type of voice was neutral, loudness was medium, pitch was acute, articulation precise, speech rate was medium.

Data concerning the professor's expressiveness based on verbal resources according to three nursing classes and comparison with the experts' opinions are summarized in the figures presented below. Differences between the assessments of speech and language experts and those by students are observed in the frequencies presented in the figures. Error bars represent standard error and the asterisk (*) indicates that the alternative chosen by most students is significantly more frequent than the remaining ( $\alpha=0.05)$.

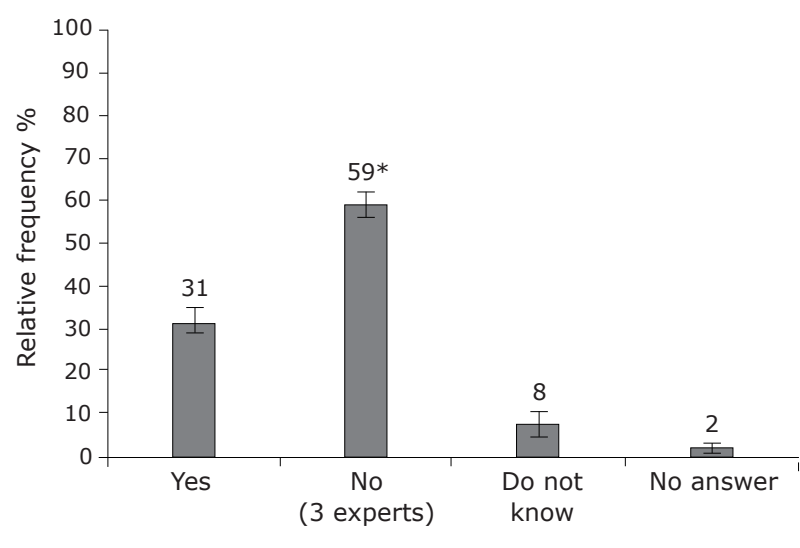

Alteration in type of voice

Figure 1 - Distribution of frequencies of the variable "Type of voice" according to the students' assessments $(n=141)$

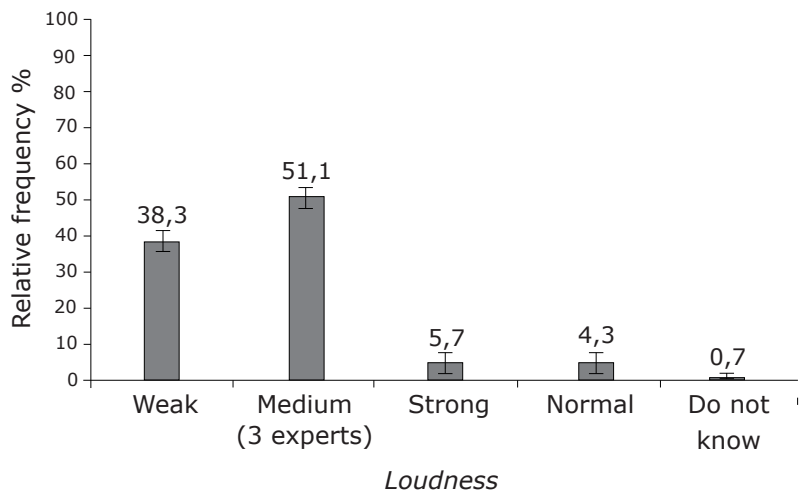

Figure 2 - Distribution of frequencies of the variable "Loudness" according to the students' assessments $(n=141)$ 


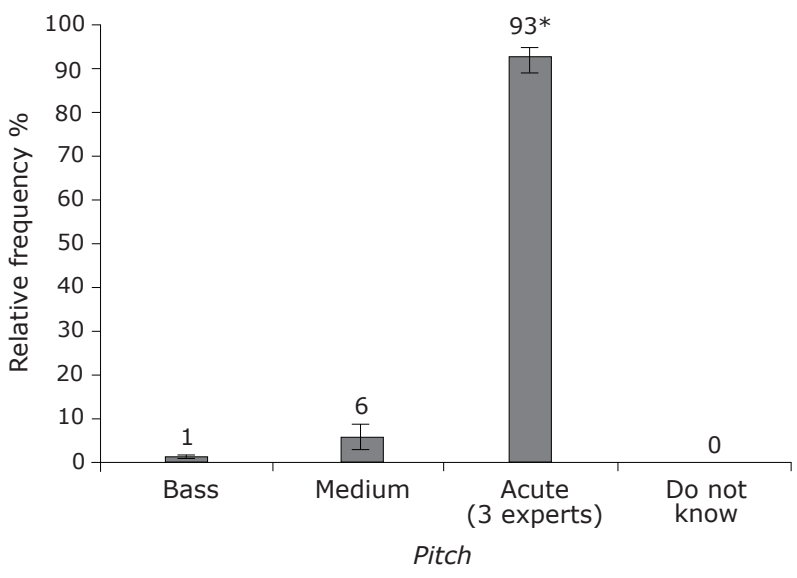

Figure 3 - Distribution of frequencies of the variable "Pitch" according to the students' assessments $(n=141)$

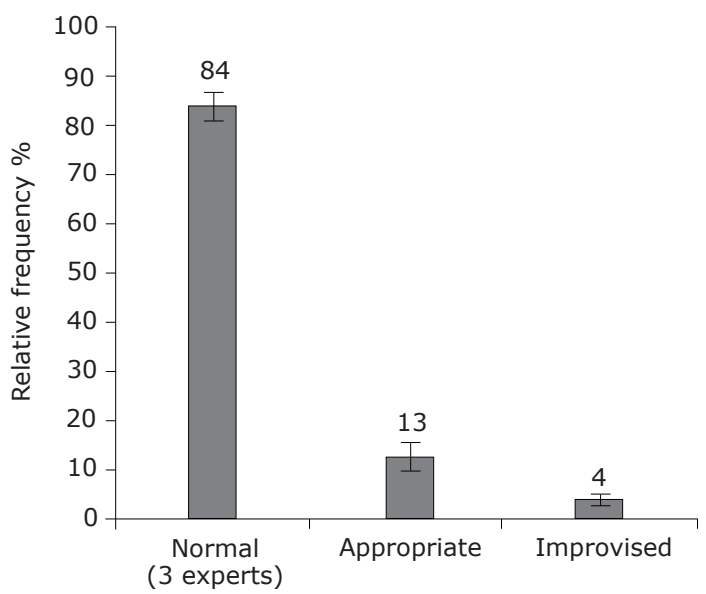

Speech articulation

Figure 4 - Distribution of frequencies of the variable "speech articulation" according to the students' assessments $(n=141)$

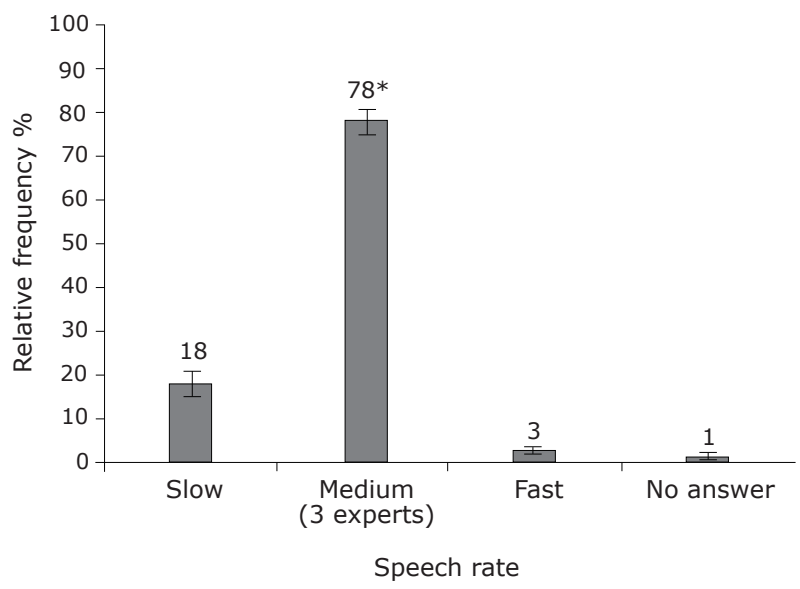

Figure 5 - Distribution of frequencies of the variable "speech rate" according to the students' assessments $(n=141)$

\section{Discussion}

The speech and language experts' assessments concerning the expressiveness of PP in relation to verbal resources (type of voice, loudness, pitch, articulation, speech rate) revealed few disagreements. Opinion was homogeneous among them and indicated they had similar professional foundations. In the specific case of this study, the experts were speech and language therapists aged between 40 and 60 years old and presented similar professional experience, worked in professional voice contexts, especially in radio and television, and had important experience with expressiveness.

Figure 1 shows that the answer chosen by most nursing students is significantly more frequent than the remaining and is in agreement with the speech language experts, that is, both groups (students and experts) did not identify alterations in PP's type of voice. It is known there are vocal complaints and dysphonia among professors in most studies we found(10-11); this professional does not know how to appropriately use voice and has no previous preparation for such use(10-15). These results are similar to a study that assessed the voices of nursing professors from a public university. The assessment of professors and experts concerning the type of voice was similar ${ }^{(13)}$. The pace and volume of audible voice was calm and pleasing to the ears. Voice pace was separated from voice volume in this study and, according to the experts, the pace of PP's voice was repetitive, that is, he speaks many times in the same rhythm ${ }^{(16)}$, which ends up hindering communication between the professor and students, making the class tiresome and leading to the students possibly becoming distracted.

In relation to loudness, most nursing students agreed with the experts that this element is medium. Figure 2 shows that the answer selected by most students is significantly more frequent than the remaining and agree with the experts' opinion. This agreement reveals that the auditory perception of both students and experts is refined, considering that the former do not have practice or experience in this type of evaluation.

The human ear has the capacity to perceive loudness $^{(17)}$ and such a fact may explain why nursing students are able to perceive it without any practice in this type of analysis. In relation to pitch and loudness, a study addressing the expressiveness of college professors concluded, after analyzing the questionnaires applied to professors and the test for expressiveness, 
that these parameters ensure greater expressiveness. Such variables increased expressiveness resources, though the study also shows that emotions interfere in one's fluency as well as in non-verbal parameters. As a result, some of the parameters that ensured a greater expressiveness were pitch and vocal intensity(6). In relation to pitch, psychophysical sensation concerning loudness taking into account bass and acute ${ }^{(13,18)}, 92.9 \%$ of the nursing students agreed with the experts in relation to the evaluated vocal parameter: they perceived that PP's pitch was acute. Figure 3 shows that the alternative chosen by most students was significantly more frequent that the remaining and agreed with the experts' opinion. This parameter, when altered in one's expressiveness, hinders the transmission of purpose of one's discourse during speech(6). Pitch was considered normal in another study by $73 \%$ of students from a chemistry diploma program, individuals who will teach this discipline in the future(12).

PP's speech articulation was considered precise by most nursing students and also by the experts when assessing the professor's speech articulation. Figure 4 shows that the answer chosen by most students is significantly more frequent than the remaining and also agreed with that provided by the experts. A study identified $67 \%$ precise articulation for most students of a chemistry diploma program; such high articulatory precision favors a message being understood. On the other hand, a total of $33 \%$ articulatory imprecision was observed and is considered high(12). Another study, in which the participants were female teachers between 22 and 62 years old, reported that age greatly affects orofacial muscles, responsible for the articulation of phonemes; the older one becomes, the more flexible the articulators ${ }^{(19)}$.

In relation to the speech rate, $78 \%$ of the students agreed with experts that it was either medium or precise. This information is presented in Figure 5, showing that the answer selected by most is significantly more frequent than the remaining and agreed with the speech language experts. Speech rate is directly related to articulation, that is, if a person articulates with precision, her/his voice rate will automatically be considered medium because phonemes will be well spoken, and the message will be understood(13-18). the speech rate evaluated in another study was considered appropriate in $54 \%$ of the students attending a chemistry diploma program, though such a rate was inappropriate in $46 \%$ of the evaluated professors ${ }^{(12)}$.
Teaching practice is determinant in professional education and the profession of professors is important considering the increased demand for learning in society. However, such a practice becomes limited if the professor's activity is restricted to the transmission of knowledge(7). Content transmitted without expressiveness may not be retained by students but rather harm their professional performance in the future.

Professors should be communicators who arouse the interest of students. For that, one needs not only to encode messages as it is usually done but decode them to students. Each professor is unique in his/her way of devising teaching strategies that will positively or negatively influence knowledge retention on the part of students in classrooms ${ }^{(20)}$.

The expressiveness of professors is a resource that regulates their interactions with students, a tool they can use to direct their actions in the classroom and organize and handle the class ${ }^{(6)}$. The classroom should be a place to display emotion, playfulness, affection and respect; it should be a place where learning relationships are subject to critique while respect remains between professors and students; individual differences should be understood and valued because they encourage the construction of knowledge(20). Clearly, this relationship is harmed if there is a lack of expressiveness on the part of professors.

A non-expressive professor or with inappropriate expressiveness can, especially in the field of nursing, harm the transmission of knowledge to students. If professors do not have an appropriate education, the goal of producing critical and reflective nurses will not be achieved. Hence, it is expected that professors overcome the act of merely transmitting information to students $^{(6)}$.

Students expect professors to have mastered course content, have credibility accruing from professional experience, use clear language during explanations, in order to acquire the desire to reflect and think together ${ }^{(4)}$ about the profession through solid argumentation. Among the factors that facilitate interaction in classrooms noted in a study with nursing students are class dynamics, relevant content, and good communication between professor and students(20).

This study's results indicate that the studied nursing students presented elements concerning assessment of PP's expressiveness similar to those presented by speech and language experts, showing their critical capacity to perform such an evaluation. 


\section{Conclusions}

This study's general objective was to assess the expressiveness of nursing professors during class in relation to their verbal resources from the perspective of students. A total of 141 students assessed the expressiveness of one professor who was also assessed by speech language experts on the same criteria.

The experts presented few disagreements among them in relation to the professor's expressiveness and in relation to the students' assessment concerning the nursing professor's expressiveness in relation to the elements: type of voice, loudness, pitch, articulation, speech rate. The results revealed that the alternatives chosen by most students were significantly more frequent than the remaining alternatives and agreed with those chosen by the experts.

The nursing students' assessment concerning the professor's expressive skills was consistent with that performed by speech and language therapists; the students of this HEI proved not to be mere spectators, but people able to properly evaluate professors.

Further studies are required to advance knowledge concerning the expressiveness of nursing professors, an essential element for their effective professional performance and consequent ability to better prepare students for professional practice in the future.

\section{References}

1. Sousa JP. Elementos de Teoria e Pesquisa da Comunicação e dos Media. 2. ed. Porto (PT); 2006. 823 p. [acesso 10 mai 2010]. Disponível em: http://bocc. unisinos.br/pag/sousa-jorge-pedro-elementos-teoriapequisa-comunicacao-media.pdf.

2. Chiavenato I. Introdução à teoria geral da administração: uma visão abrangente da moderna administração das organizações. 7 . ed. Rio de Janeiro (RJ): Elsevier; 2004.

3. Kyrillos LR, organizadora. Expressividade: da teoria à prática. Rio de Janeiro (RJ): Revinter; 2005.

4. Stier MA, Costa B. Expressividade: falar com naturalidade e técnica no jornalismo de televisão. In: Kyrillos L, organizadora. Expressividade: Da teoria à prática. Rio de Janeiro (RJ): Revinter; 2005. p. 179-96.

5. Ferreira $\mathrm{ABH}$. Novo Dicionário Aurélio da Língua Portuguesa: revista ampliada. 2. ed. Rio de Janeiro (RJ): Nova Fronteira; 1986.

6. Barbosa N, Cavalcanti ES, Neves EAL, Chaves TA, Coutinho FÂ, Mor EF. The expressiveness of the university teacher as cognitive factor in the teach-leaming. Ciênc Cogn [periódico na Internet] 2009; 14(1) [acesso 4 maio 2011], 75-102. Disponível em http://pepsic.bvsalud. org/scielo.php?script=sci_arttext\&pid=S180658212009 000100006\&Ing=pt\&nm=iso. ISSN 1806-5821.

7. Rodrigues MTP, Mendes SJAC. Enfermeiro professor: um diálogo com a formação pedagógica. Rev Bras Enferm. [periódico na Internet]. ago 2007 [acesso 17 abr 2011]; 60(4):456-459. Disponível em: http://www. scielo.br/scielo.php?script=sci_arttext\&pid=S003471672007000400019\&Ing=en. doi: 10.1590/S003471672007000400019.

8. Feijó D. Avaliando a comunicação oral. In: Kyrillos LR, organizadora. Fonoaudiologia e Telejornalismo. São Paulo (SP): Revinter; 2003. p. 75-88.

9. Ministério da Saúde (BR). Conselho Nacional de Saúde. Diretrizes e normas regulamentadoras de pesquisa envolvendo seres humanos: Resolução $\mathrm{n}^{0}$ 196/96. Brasília (DF): Ministério da Saúde; 1996.

10. Penteado RZ, Pereira IMTB. Qualidade de vida e saúde vocal de professores. Rev Saúde Pública. [periódico na Internet]. abr 2007. [acesso 14 dez 2009];41(2):23643. Disponível em: http://www.scielosp.org/scielo. php?pid=S0034-89102007000200010\&script $=$ sci arttext

11. Romano CC, Alves LA, Silva AL, Marziale MHP, Robazzi MLCC. Alterações vocais decorrentes do trabalho em professores: uma revisão de bibliografia. Rev Enferm UFPE. [periódico na Internet]. jul-set 2009. [acesso 14 dez 2010];3(3):269-77. Disponível em: http://www. ufpe.br/revistaenfermagem/index.php/revista/article/ view/183/183

12. Chaves TA, Coutinho FA, Mortimer EF. A expressividade do futuro professor de química: recursos verbais e não verbais. Rev Bras Ensino Ciênc Tecnol. (RBECT). 2009;2(1):1-17.

13. Alves LA. Parâmetros vocais e percepção vocal de professores universitários [dissertação de Mestrado] Ribeirão Preto (SP): Escola de Enfermagem de Ribeirão Preto da Universidade de São Paulo; 2007. 215 p.

14. Vieira AC, Behlau M. Análise de voz e comunicação oral de professores de curso pré-vestibular. Rev Soc Bras Fonoaudiol. 2009;14(3):346-51.

15. Salas SWA, Centeno HJ, Landa CE, Amaya CJM, Benites GM Del R. Prevalência de disfonía en profesores del distrito de Pampas - Tayacaja- Huancavelica. Rev Med Hered. [Internet.] jul-set 2004. [acesso 12 dez 2009]15(3):125-30. Disponível em: http://www.upch. edu.pe/famed/rmh/15-3/v15n3ao1.pdf 
16. Rocha EM. O comportamento comunicativo docente de enfermagem e sua influência na aprendizagem do educando. [dissertação de Mestrado] São Paulo (SP): Escola de Enfermagem de Ribeirão Preto da Universidade de São Paulo; 1999. 101 p.

17. Medeiros EB. Introdução a teoria acústica. Belo Horizonte: Universidade Federal de Minas Gerais [Internet]. [acesso 16 jul 2010]. Disponível em: http://www.cpdee.ufmg.br/ semea/anais/artigos/ EduardoBauzer.pdf

18. Behlau M, Pontes P. Avaliação e tratamento das disfonias. São Paulo: Lovise; 1995.

19. Troni CR, Arakaki FN, Lima FS, Mott L, Rodrigues KA, Ferreira LP. Professores em contexto profissional e não profissional: análise objetiva e subjetiva dos aspectos da articulação e da postura. Distúrbios Comun Hum. ago 2006;18(2):179-88.

20. Rocha EM, Silva MJP. Changes in classroom relations and their influence on learning. In: Proceedings of the 8. Brazilian Nursing Communication Symposium [Proceedings online]; 2002 May 02-03; São Paulo, SP, Brazil. 2002 [acesso 7 mai 2011]. Disponível em: http:// www.proceedings.scielo.br/scielo.php?script=sci_arttext $\&$ pid=MSC0000000052002000200023\&lng=en\&nrm=van 